\title{
食道静脈瘤出血に対する胃上部切除術
}

\author{
名古屋大学第 2 外科 \\ 秀村立五 \\ 爱知医科大学第 1 外科 \\ 山本貞 博

\section{TERMINAL ESOPHAGO-PROXIMAL GASTRECTOMY (TEPG) FOR BLEEDING ESOPHAGEAL VARICES}

\section{Ryugo HIDEMURA}

The 2nd Department of Surgery, Nagoya University School of Medicine)

Sadahiro YAMAMOTO

The 1st Department of Surgery, Aichi Medical College)

索引用語：胃上部切除術, 胃上部横断術, 直達手術, 食道静脈溜, 門眼圧亢進症

\section{I はじめに}

門脈圧光進症の三主徽, 腹水, 脾腫, 食道静脈瘤のう ち，現在腹水は内科的治療対象之なり，翼㹸も血行路的 清の一環として剔出が考慮ざれるべきものであって，外 科的治療対象は食道静脈溜のみである。したがって外科 治療の立場からは，門脈圧充進症は食道静脈瘤柱之換言 できる。

門脈圧がえ進した病態の主要改候として出現する食道 静脈瘤に対して，門脈圧を下降させて治療目的を達する 門脈下大静脈吻合術を典型とする血管吻合術は非常に效 果的である。しかし，肝硬変性の門脈圧六進症では，吻 合術後に肝不全が出玩しやすく，食道静脈瘤からの出 を防止できても，後に遺る肝機能不全のため血管吻合術 は適用できない，私どは154例の門脈下大静脈吻合術 を中心とする門脈減圧手術の予後追跡の結果，师脈生を 下降して食道静脈瘤の治療目的を達する術式は，とくに 肝硬変性門脈圧元進症に選択すべさでないという結諭を 報告してきた。

すなわち門脈比の元進状態は, 胙に多军の血液を送り

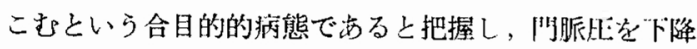

* 第11回日消外総会シンポ II 食道静脈瘤の直達手術とその適応
させることなく, 食道静脈瘤からの出血を防止する直達 手術術式の転换をして久しいのである。

ここには食道静脈衙の成り立ち上り，胃上部切除術を 典型とする值達手術を選択した根拠を述へ，との成績を 郝告する。

\section{II 対象と術式}

今回私どもが 検討の対象とした胃上部切除術施行例 は, 140例であり, その中16例が肝外門脈閉塞症, 21例 が肝内門脈閉塞症, 100 例が 肝内肝静脈閉塞症, 残りの 3 例が肝外肝静脈閉塞症であった。

これらの成續を, 血管吻合術の典型であった阿眽下大 静脈吻合術 154 例の成續と比輬し, また面達手術の变法 である胃上部横断術 50 例の成績とる比較検楌した。

近年, 門脈纴九進症の大半は肝硬変性門脈王充進症が 占好るよらになり, また非硬変性門脈王穴進症は予後が 良好であるので，肝硬変性門脈圧充進症仼重点をおいて 成績を分析した。

食道静脈瘤の成り立ちについて, 術前術中の血管撮 影，食道毁譬像扣よび食道鏡所見等と手術によって得ら れた食道下部胃上部の切除組織の連続切片血管像を追跡 し、再構筑法によって検沽した結果は, 図1のごとく胃 壁外の冠状静脈系および短胃静脈系の血行之，胃壁の筋 痽間および粘膜下を通過して来た血行が食道粘膜下で合 
第 1 図胃上部食道下部血行模型图

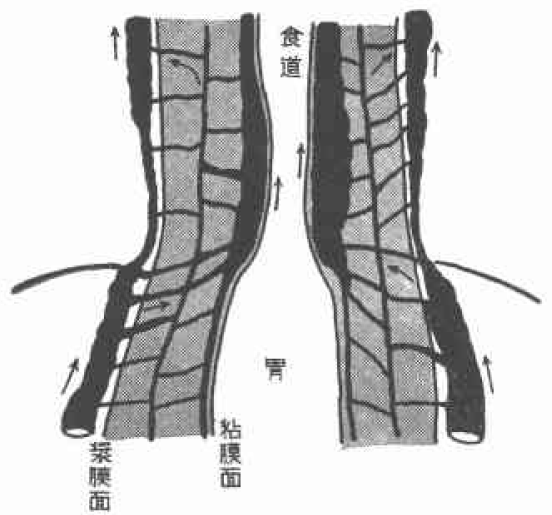

流し，食道静脈瘤が形成されると判断された。

したがって，直達手術の目的を達するとは，この食道 に流入する胃壁外と胃壁内の血行路を遮断することが必 要である。

胃上部切除術とは，上腹部 $\mathrm{L}$ 字切開にて開腹，脾剔拉 よび食道下部と胃上部の血行嫁清が第 1 段階である。こ れによって胃壁外から食道に 注ぐ副血行路は遮断され る. 食道は 8 乃至 10 粴の長さとおいて血行廊清を施行す るのである、次いで食道下部々胃上部を幅約 5 糎切除す る操作が第二段階である。これ沉っって胃壁に存在して 食道に注ぐ血行路が遮断される．その後，切断された食 道と胃前壁の端側吻合を施行，さらに食道周囲の血行廓 清時の迷走神経切断に対して Heineke-Mikulicz 法にて 幽門成形術を併施するが，こ机が第三段掯である.脾剔 は左胃大網静脈蛒よび短胃静脈から食道静脈瘤への副血 行路遮断が主目的であり，結果として脾機能立進の除去 飞役立つ，胃上部を切除する根扰は，前述したごとくこ の部に食道静脈瘤への副血行路が身中するからである。

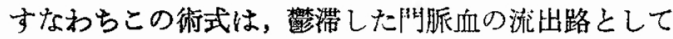

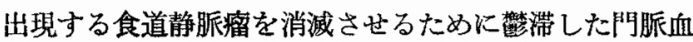
を食道静脈䭒へ流入させない状態を作製することを目的 とするのである.

\section{III 成}

胃上部切除術の成績は，肝実質の障害度にしたがって 検討されなけれぱならない。すなわち進行性病変である

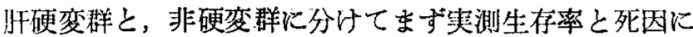
ついて検討した.

非硬変性 の 肝外門脈閉塞症16例の 5 年生存率は 93.4 $\%, 10$ 年以降 $85.8 \%$ であり，肝内門脈閉塞症 21 例では,
第 2 四胃上部切除術後の実測生存率

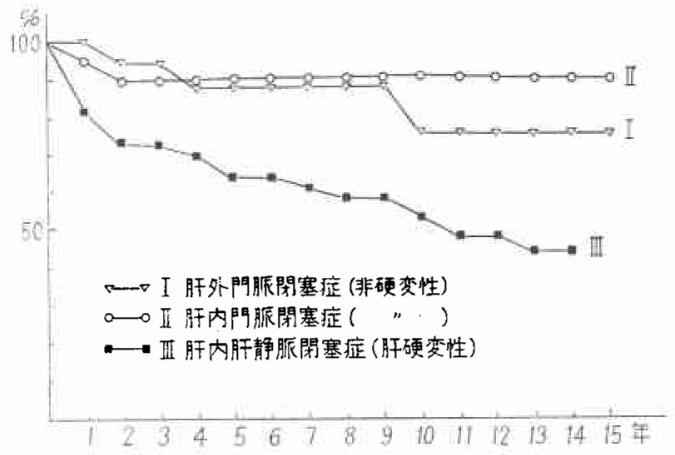

2 年以降 $90 \%$ 之高い生存率であった (図 2 参照).朋外門 脈閉塞症の死因は, 術後 1 年と 3 年の交通事故死が 2 例, 他のI例は，胃上部妸除術後も吐血し，経啲的食道離断 を併施するす吐血死した。術後10年 2 力月で方った。肝 内門脈閉塞症の死亡例は，桾尿病症例で術後 DIC 古 许した術死 1 例と，術後 1 年経過し急性肘不全で死亡し たと他院から報告のあった1例である。

これに対して, 肝硬変性の肝内肝静脈閉塞症100例の 实測生存率は，5年 $64.4 \% ， 10$ 年 $52.7 \% ， 15$ 年 $43.6 \%$ で 茜った，非硬変群に比し低率であるが，阿脈下大静脈吻 合術の実測生存率 5 年 $22.4 \%, 10$ 年 $11.6 \%$ に比し良好な 成績である。

第 1 表 胃上部切除術後死因（肝硬变性閇脈圧 六進症）

\begin{tabular}{|c|c|c|c|}
\hline 術 & & 死 & 10 例 \\
\hline 看 & 不 & 全 & 13 \\
\hline 出 & 血 & 死 & 8 \\
\hline 肝 & & 癌 & 4 \\
\hline 輸 升 & 血後肝 & 炎 & 2 \\
\hline 脳 & 出 & 血 & 1 \\
\hline
\end{tabular}

この肝硬変群の死因は, 表 1 のごとく, 術後 1 カ月内 に死亡した 術死10例（この中に 肝不全例 5 例 が 含まれ る。),肝不全 13 例怙よび出血死 8 例などである。これら の術死および肝不全による死亡例の多くは，手術開拓期 の高度肝障害例であった。

次に術後出血について検討した。非硬变群である朋外 門脈閉塞症の術後出血は 2 例にみられ，その 1 例は術後 10年 2 力月の死亡例である. 肝内門脈閉塞症には術後出 血はなかった。これに対して訮硬変群である肝内肝静脤 
第 . 図䡒上部切除術後出血症例

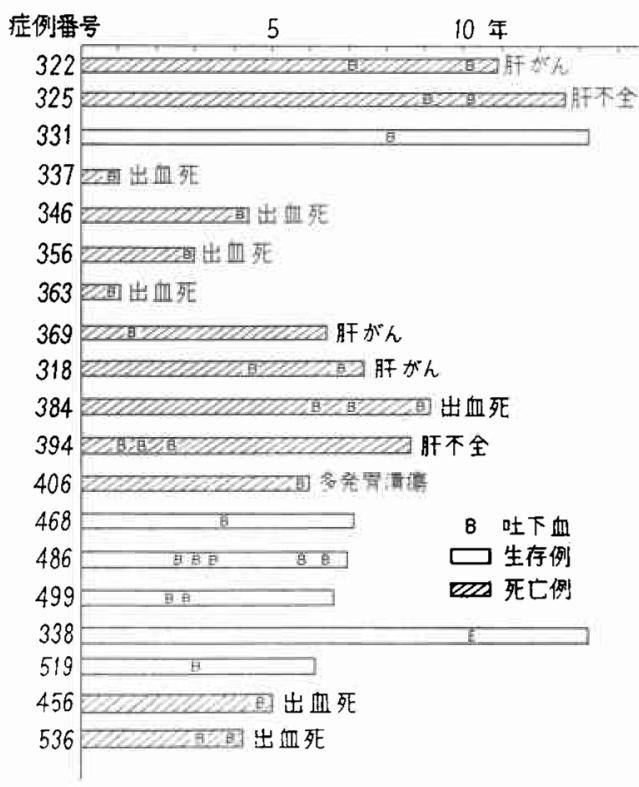

閉塞症:の術後出血は図 3 のごとく19例である．その中 8 例が出血死亡例であるが，開拓期の症例に多い，その他 は術後消化管出血があってる，死因となる出血でなく， 術後長期生存して肝癌で 3 例, 朋不全で 2 例が死亡して いる.

この肝硬変性門脈压立進症の100例を, 前半と後半の 50 例ずつに分けると前半は 7 年，後半は7.5年に50例ず つ施行された事になる.前半の術後消化管出血は14例，

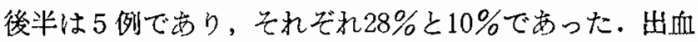
死亡率は前半 $14 \%$, 後半は $2 \%$ あ゙あた（表 2 ).ここで

第 2 表 年度別術後消化管出血（肝硬変性門脈圧宇 進症）

\begin{tabular}{|c|c|c|}
\hline 年度 & H血例 & 死亡婹! \\
\hline $1964 \sim 1970$ & $14 / 50(28.86)$ & $7 / 50(14 \%)$ \\
\hline $1970 \sim 1977$ & $5 / 50(108)$ & $1 / 50(296)$ \\
\hline
\end{tabular}

明確にしておくべきことは; 術後消化管出血とは, 静脈 瘤出血のみを意味するるのではないことである.すなわ ち吐血死亡した剖検例に静脈瘤はなく胃に多発潰瘍が認 められたこと，また吐血後の食道鏡検查で静脈瘤は認め られず吻合部に近い食道糜爛を認めた例などがあるので むる。

一方肝内性門脈圧圥進症でありながら, 非硬変性の朋
第 4 図

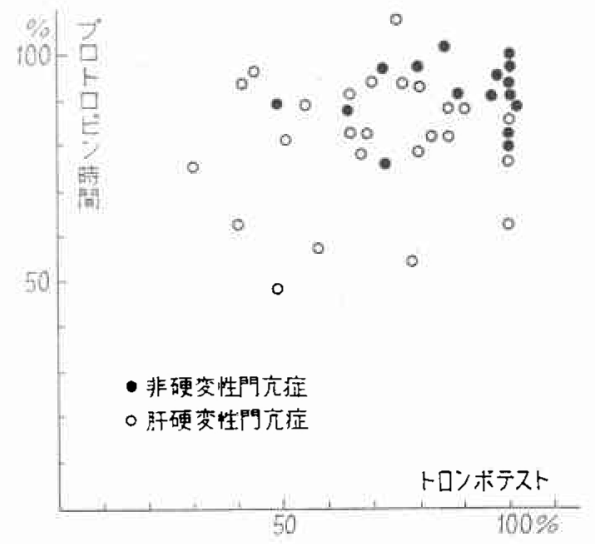

内門脈閉塞症には，術後に消化管出血がない事は肝硬変 性の肝内肝静脈閉塞掟と著しい差である。これは凝固能 に関する 2 つのストであるプロトロンビン時間とトロ ンボテストについて, 非硬変性の肝内門脈閉塞症と硬変 性の肝内肝静脈閉塞症の成績を比較すると, 術後出血率 とよく符合するのである (図 4 参照).

ここで本術式の手術適応について述べる. 胃上部切除 術の開拓期からの 手術例の 術前臨床検查などの 分析か ら, 手術目的を達して 5 年以上の長期生存をえるには, 次のような安全適応限界をえた。すなわち、アルブミン $3 \mathrm{~g} / \mathrm{dl}$ 以上, BSP $\left(30^{\prime}\right) 30 \%$ 以下, KIGG 0.1 以上, 閉 塞肝静脈圧 $250 \mathrm{mmH}_{2} \mathrm{O}$ 以下, Bilirubin $2.0 \mathrm{mg} / \mathrm{dl}$ 以下, 腹水がない，肝性脳症がない，年龄は60歳以下などであ る:

第 5 図，肝硬変性門脈王元進症の実測生存率

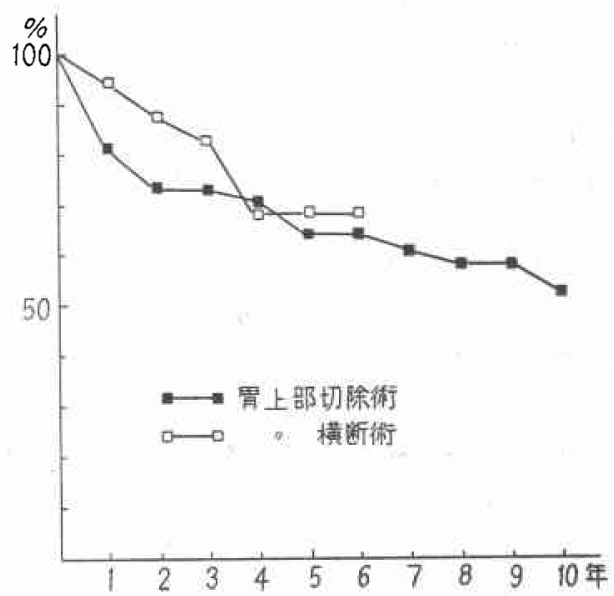


これらの安全適応限界を越えた症例は，長期生存例が 少ないので，成績の向上を意図して胃上部横断術を考按 乙検討中であるが胃上部切除術との差は胃上部を切除す ることなく，E-C junctionより約 5 糎の胃上部を完全に 雔断後再建することである。

この術式を50例に施行した. 肝外門脈閉塞症が 4 例, 肝内門脈閉塞症が 12 例, 肝内肝静脈閉塞症が 34 例であ る. 非硬変性の前二者16例には，若年者に対する胃機能 保存の意味で滴用されたが出血による死亡も, 又他の原 因炕上る死亡むない。したがって肝硬变性の肝内肝静脈 開塞症のみの実測生存率を求めると図 5 のごとく，5年 生存率 $69 \%$ と胃上部切除術の生存率と略一致する. 死亡 例は胃上部妡除術と同様に，肝不全㧍よび肝機能障害に よる出血が多い。

\section{IV 考 察}

門脈圧九進症の圧光進を病的肝飞対する合目的的病態 として捉え，この压立進を残して，出血の危険のある食 道静脈瘤を消減させる直達手術としての胃上部切除術に ついて, 術式の根拠と成績を述べた。

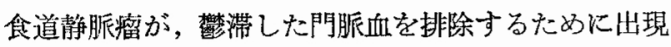
した副血行路であれば，この静脈瘤治潦の三原則は，供 給路の噺清，局所処置及び排出路の温存といえよう。

供給路の㨯清は，これを広筑且確実に行ってこそ，そ の目的を卖するものである. Phemister や Hunt をはじ め類似の術式の成績が良好でなかったのに比し，私ども の成績が良好である理由は，まずこの廊清の広さと確実 さにあるといえよう。すなわち脾剔を含め左胃大網静脈 および短胃静脈を碚清し，小竔側山左胃動脈を含めて左 胃静脈を，さらに胃後面の脾静脈と連絡する無名静脈を 十分飞敦清する．とくに食道裂孔周辺の廓清を入念に行 うことが，食道静脈鲨再発防止につながる。開拓期の成 縝が悪かった理由は，適応設定とこの障清が不十分であ ったものと判断された，廓清時にとくに留意すること は，胃上部の胃漿膜の損傷をさけることであり，胃周边 の廍清は指尖をるって施行すべきである。

次に局所処置の場として, 再構築模型図に示したごと く，最も副血行路の集中する胃上部を切除することは， 静脈瘤の直達手術の原則にのっとった処置といえよう。 局所雗断を確実にするためには，一部切除することが基 本であるが最小の切除といら観点から，前述したごとき 胃上部横断術を施行して，目下経過を観察中である.

食道静脈瘦へ流入した血液は，奇静脈半奇静脈を経て
心臟汇環流するものであって，この流出路はむしろ温存 すべきものであり，私どは E-C junction 上り8乃至 $10 \mathrm{~cm}$ の遊清範囲を流入路の遮断域と考え, これより口 側は流出路として温存している。

私どもの直達手術は，かくのごとくすべて経腹的に行 われ，また経腹的に十分目的を達するすのである．経胸 的に食道下部に到達することは，経腹的より容易ではあ

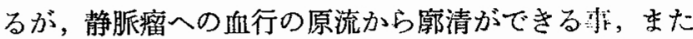
門脈圧測定, 閒脈撮影が十分飞行われ，から肝の肉眼的 組織学的観察が可能である点など，経腹的手術の方が命 理的であり且有用である.

緊急手術は可能なかぎり避けて，待期手術㳊行させ る、緊急時には、バルーンタンポナーデと新鮮血輸血に て止血し， 1 乃至 2 週後に，出血ショックによる新たな 肝障害の程度を理解して手術を施行すべきである。

予防的手術については，食道鏡所見で，青または赫仙 の結節性静脈瘤を対象とするが，手術方法には特別工夫 する点はなく，原則にしたがって施行する。

また門脈圧穴進を招来した原疾急の違いによって術式 の変りはない。

次に手術成績について述べる．非硬変性のグルーブに ついては甚だ良好な結果であって問題はない，肝硬变性 の肝内肝静脈閉塞症の実測生存率は原疾患の性質上, 非 硬変性のものより劣るが門脈減圧術上り甚だ良好であり かつ同程度の肝機能障害のある非手術例飞比し良好な子” 後といえる，成績の一端である術後出血については，非 硬変珄の肝内門脈閉塞症は術後出血もなく経過良好であ る. 硬変性の肝内肝静脈閉塞症には19\%の再出血率がか った.これを開拓期を含めた前半と, 後半に分けると, それぞれ28\%と10\%であった。この18\%の差は，部消を 中心とした手技の改良と術後管理の向上による結果と考 えられるが，な打非硬変性のグルーブとの間に差があ る。これは凝固能成績で示したごとく，背景にある肝硬 変による出血傾向また胃食道粘膜の脆弱性によるすのて ある.すなわち術後出血は残存食道静脈瘤からのみでな く生充進のある粘膜静脈からも出血しやすいので, 術後 は粘膜保護收斂凧の服用，またアルコールなどによる筒 炎食道炎の発生を防止することが良好な予後汇通ずるの である。そ理由は，非硬変性の肝内門脈閉塞症に術後 出血例がない事実で，本術式が技法としては完成された ものであるといえるからである。

\section{$\mathbf{v}$ 結 語}

門脈圧元進症の食道静脈瘤直迩手術について，胃上蔀 
切除術を中心にその術式の根拋と成績を述へたた. とくに 非硬变性の肝内門脈閉塞症之肝硬变性の肝内肝静脈閉塞 痽の成績を比較し，手術々式は完成されたるのであり， 硬変性の肝内肝静脈閉塞症の術後出血は, 肝硬变を背景 にした出血傾向および胃食道粘膜の脆弱性に起因するこ とを述べた。

\section{文 献}

1) 今永一：わが国に拈ける門脈圧九進症の特 性. 日外会誌, 65：1055，1964。

2) Phemister, D.B. and Humphreys, E.M.: Gastroesophageal resection and total gastrectomy in the treatment of bleeding varicose veins in Banti's syndrome. Ann. Surg., 126: $397,1947$.
3) Hunt, A.: A contribution to the study of portal hypertension. Livingstone. Edinburgh \& London, 1956.

4) 山本貞博: 胃上部切除術. 外科治撩, $26: 643$, 1972.

5) Yamamoto, S., Hidemura, R. et al.: The late results of terminal esophago-gastrectomy (TEPG) with extensive devascularization and splenectomy for bleeding esophageal varices in cirrhosis. Surgery, 80: 106, 1976.

6) 山本貞博, 秀村立五, 竹重言人: 食道静脈瘦飞 対する胃上部切除術。手術, 30:461, 1976 。

7) 荒木一文, 永田虔二, 中川昌壮：ICG 試験より 又た肝疾患の予後一肝臟最大排泄能, 比較的眝 藏能を含めて, ICG 研究会講演集, 46, 1976. 